University of Nebraska - Lincoln

DigitalCommons@University of Nebraska - Lincoln

West Central Research and Extension Center, North Platte

Agricultural Research Division of IANR

$12-2009$

\title{
Spatio-Temporal Relationship between Water Depletion and Root Distribution Patterns of Centaurea solstitialis and Two Native Perennials
}

\author{
Stephen L. Young \\ University of Nebraska - Lincoln, steve.young@usu.edu \\ Guy B. Kyser \\ University of California, Davis \\ Jacob N. Barney \\ University of California, Davis \\ Victor P. Claassen \\ University of California, Davis \\ Joseph M. DiTomaso \\ University of California, Davis, jmditomaso@ucdavis.edu
}

Follow this and additional works at: https://digitalcommons.unl.edu/westcentresext

Part of the Agriculture Commons

Young, Stephen L.; Kyser, Guy B.; Barney, Jacob N.; Claassen, Victor P.; and DiTomaso, Joseph M., "SpatioTemporal Relationship between Water Depletion and Root Distribution Patterns of Centaurea solstitialis and Two Native Perennials" (2009). West Central Research and Extension Center, North Platte. 7.

https://digitalcommons.unl.edu/westcentresext/7

This Article is brought to you for free and open access by the Agricultural Research Division of IANR at DigitalCommons@University of Nebraska - Lincoln. It has been accepted for inclusion in West Central Research and Extension Center, North Platte by an authorized administrator of DigitalCommons@University of Nebraska - Lincoln. 


\title{
Spatio-Temporal Relationship between Water Depletion and Root Distribution Patterns of Centaurea solstitialis and Two Native Perennials
}

\author{
Stephen L. Young, ${ }^{1}$ Guy B. Kyser, ${ }^{2}$ Jacob N. Barney, ${ }^{2}$ \\ Victor P. Claassen, ${ }^{1}$ and Joseph M. DiTomaso ${ }^{2}$ \\ ${ }^{1}$ Department of Land, Air, and Water Resources, University of California, Davis, CA 95616, U.S.A. \\ 2 Department of Plant Sciences, University of California, Davis, CA 95616, U.S.A. \\ Corresponding author - J. M. DiTomaso, email jmditomaso@ucdavis.edu
}

\begin{abstract}
In a 2-year field study, we quantified lateral root growth patterns and soil water depletion dynamics in the invasive annual Centaurea solstitialis and two native perennials, Elymus glaucus and Grindelia camporum. Centaurea solstitialis produced lateral roots most actively from early April to mid-June, during the late rosette to spiny seedhead stage while both root growth and water depletion were completed before flowering. In the wet year, roots were evenly distributed throughout the soil profile to $180 \mathrm{~cm}$ deep. Lack of deep soil moisture recharge in the second year restricted root distribution to shallow soil depths ( $<60 \mathrm{~cm})$. In contrast to C. solstitialis, living roots of the native perennials persisted throughout the year. Elymus glaucus roots were most abundant (47\% of total roots) in the upper soil profile $(\leq 60 \mathrm{~cm})$ in the wet year, but most abundant $(55 \%)$ in the lower profile $(\geq 150 \mathrm{~cm})$ in the dry year. However, the distribution of G. camporum roots was comparable between the 2 years. This indicates that in years with little to no deep soil moisture recharge, $C$. solstitialis roots are distributed in the shallow soil profile similar to annual grasses, whereas in wetter years it is similar to deep-rooted perennial species. We also show that $C$. solstitialis impacts grassland communities by depleting soil moisture during the short period of lateral root growth from the late rosette to the spiny stage. Therefore, control of $C$. solstitialis early in the season is critical during native plant restoration where success depends upon available soil moisture.
\end{abstract}

Keywords: biological invasions, Elymus glaucus, grassland restoration, Grindelia camporum, yellow starthistle

\section{Introduction}

In Mediterranean climates, soil moisture recharge occurs almost entirely between late fall and early spring. During years of normal rainfall, the soil typically recharges to a depth of $2 \mathrm{~m}$ or more. During late spring and summer, there is a steady decline of soil moisture in most of the profile. For example, in California, late summer soil moisture potentials can range from -0.5 to $-4.5 \mathrm{MPa}$, depending on vegetative plant cover (Gerlach 2004). Native grassland species depend on their ability to efficiently extract deep soil moisture following annual fall and winter recharge (Holmes \& Rice 1996; DiTomaso et al. 2003; Young et al. 2009). In these systems, the spatio-temporal relationship between water use and root distribution patterns is poorly understood.

Yellow starthistle (Centaurea solstitialis L.) is a winter annual forb that can be found in much of the United States, extending as far East as New York, and other areas of the world including nearly all Mediterranean climates and most temperate regions (Maddox et al. 1985). In California, C. solstitialis is estimated to infest 600,000 ha and represents the most widely distributed invasive species in the state (Duncan et al. 2005). Despite our limited understanding of the spatio-temporal relationship between water depletion and root distribution patterns in C. solstitialis, it is has been shown to successfully compete with other species for soil moisture (Enloe et al. 2004; Gerlach 2004).

In this study, we compared two historically prominent native herbaceous perennial species of this region, blue wildrye (Elymus glaucus Buckley) and common gumplant (Grindelia camporum Greene) with C. solstitialis. Unlike the two native species, $C$. solstitialis has ruderal characteristics including high-seed production (Roché et al. 1994), reduced seed dormancy, and rapid root development (Sheley et al. 1993; Benefield et al. 2001). Despite being a winter annual forb, $C$. solstitialis appears to be functionally similar to many native perennial grasses and forbs in its resource allocation patterns and phenology (Gerlach \& Rice 2003; Gerlach 2004; Young et al. 2009). Elymus glaucus is morphologically different (fibrous roots and narrow leaves) than C. solstitialis, but is proposed to be functionally similar to its root distribution pattern and soil water use timing (Young et al. 2009). This hypothesis is based on the ability of E. glaucus to resist C. solstitialis invasion under Central Valley grassland conditions (Young et al. 2009). 
In addition, E. glaucus is considered to be one of the better adapted and more robust perennial grasses native to the Sacramento Valley (Knapp \& Rice 1996; Bugg et al. 1997). Grindelia camporum, a perennial forb, is more closely related taxonomically and morphologically to C. solstitialis. Both G. camporum and $C$. solstitialis are characterized by deep rooting systems and mid-summer growth and flowering. Because of apparent functional similarity and widespread abundance, E. glaucus and G. camporum have the potential to suppress $C$. solstitialis in grassland restoration projects (Bugg et al. 1997; Claassen \& Marler 2004).

We hypothesize that the ability of these native species to resist C. solstitialis invasion is due to their functional similarity in root distribution and water resource acquisition timing. We therefore undertook to assess the seasonal root growth dynamics and water depletion patterns of these three species grown under field conditions. We predicted that the invasive $C$. solstitialis develops an extensive root system with a distribution and water depletion pattern similar to the native perennials.

\section{Methods}

\section{Study Area and Plant Species}

This study was conducted in the Sacramento Valley near Davis $\left(38^{\circ} 33^{\prime} \mathrm{N}, 121^{\circ} 48^{\prime} \mathrm{W}, 18 \mathrm{~m}\right.$ elev.), California, where mean annual precipitation is approximately $480 \mathrm{~mm}$. The area is converted grassland, previously under agricultural production. The dominant vegetation included nonnative annual grasses and forbs. The soil was a silt loam with less than $1 \%$ slope, mapped as a coarse-loam mixed superactive non-acidic Thermic Typic Xerofluvent (Huntington et al. 1981).

The field site consisted of $4 \times 4-\mathrm{m}$ plots with $1.5-\mathrm{m}$ buffers. Three replicates of each monoculture of Centaurea solstitialis, Elymus glaucus, and Grindelia camporum, plus bare ground controls, were arranged in a randomized complete block design. In 2001, C. solstitialis seeds, collected from local infestations, were broadcast seeded at $2 \mathrm{~kg} / \mathrm{ha}$. In 2000, we seeded E. glaucus at a rate of $22.4 \mathrm{~kg}$ pure live seed per hectare. These plots were maintained for several years until the initiation of this study in 2006. We transplanted greenhouse grown seedlings of G. camporum on 20 February 2006, on $30 \mathrm{~cm}$ centers (approximately 200 plants per plot). The seedlings were approximately 3 weeks old with an average of four leaves per plant, $4.4 \mathrm{~cm}$ in height, and 12.6 $\mathrm{cm}$ in diameter. Bare ground control plots were kept free of vegetation for the duration of the study with glyphosate applications, and monoculture plots were hand weeded to remove other species. Natural precipitation provided the only source of water.

We installed nine subterranean root observation chambers at the edge of the plots during the spring and summer of 2005. Each chamber consisted of a $1.2 \mathrm{~m}$ long $\times 1.2 \mathrm{~m}$ wide $\times 2.4 \mathrm{~m}$ deep compartment with a glass observation window $(1.2 \mathrm{~m}$ wide $\times 1.8 \mathrm{~m}$ deep). We placed a wire grid $(7.4 \times$ $4.9 \mathrm{~cm}$ cells) on the chamber window to facilitate root measurements. Chambers were installed on the North side of the plots with the window facing South to eliminate exposure of roots to direct sunlight. A plywood roof overlaid with corrugated metal sheeting covered the chambers at an angle that drained precipitation away from the viewing surface.

Excavation of the observation chambers caused minimal disturbance of the existing root/soil system. The soil profile was cut so that only a small gap $(5-6 \mathrm{~cm})$ had to be back filled between the outer surface of the observation window and the undisturbed soil/root profile.

\section{Root Growth}

Root growth was estimated by counting and measuring diameter of live roots within each grid along the various depth intervals. Mean root production (roots per square $\mathrm{cm}$ ) at each timing was determined for each species from root counts taken at 30,60,90,120,150, and $180 \mathrm{~cm}$ depths. In 2006, roots were measured weekly following the appearance of roots on the viewing window beginning in early spring and continuing through fall. In spring 2007, biweekly root counts began at the first appearance of $C$. solstitialis roots. At each measurement, the phenological stage of development was recorded for all three species.

\section{Soil Moisture}

A neutron probe (Model \#503, CPN Inc., Pacheco, California, U.S.A.) was used to measure soil water content (SWC) weekly or biweekly at 30,60,120, and $180 \mathrm{~cm}$ depth. In 2000, neutron probe access holes were drilled in the center of each plot to approximately $2 \mathrm{~m}$ in depth. Neutron probe measurements were converted to volumetric SWC (DiTomaso et al. 2003), which is reported as a percentage.

\section{Statistical Analysis}

Soil moisture was evaluated between species within each year using analysis of variance (ANOVA). We compared the mean SWC of C. solstitialis with G. camporum or E. glaucus using pair-wise contrasts in the shallow and deep soil at several phenological stages. We graphed Februaryto-September soil water depletion for each species in relation to bare ground controls. All statistical analyses were performed using SAS (SAS 2002).

\section{Results}

\section{Precipitation Patterns}

Precipitation differed substantially between the 20052006 and 2006-2007 seasons (Figure 1). Cumulative precipitation in 2005-2006 was $594 \mathrm{~mm}$, or $124 \%$ of the 30-year normal of $480 \mathrm{~mm}$. In particular, there was $250 \mathrm{~mm}$ precipitation from early February to mid-April 2006, $162 \%$ of normal for that period. In contrast, precipitation in 2006-2007 totaled only $242 \mathrm{~mm}$ ( $50 \%$ of normal), and rainfall from early February to mid-April was $71 \%$ of normal. Following normal winter recharge, deep soil $(120 \mathrm{~cm})$ water content in bare ground plots was 25\% v/v in early April 2006 (Figure 


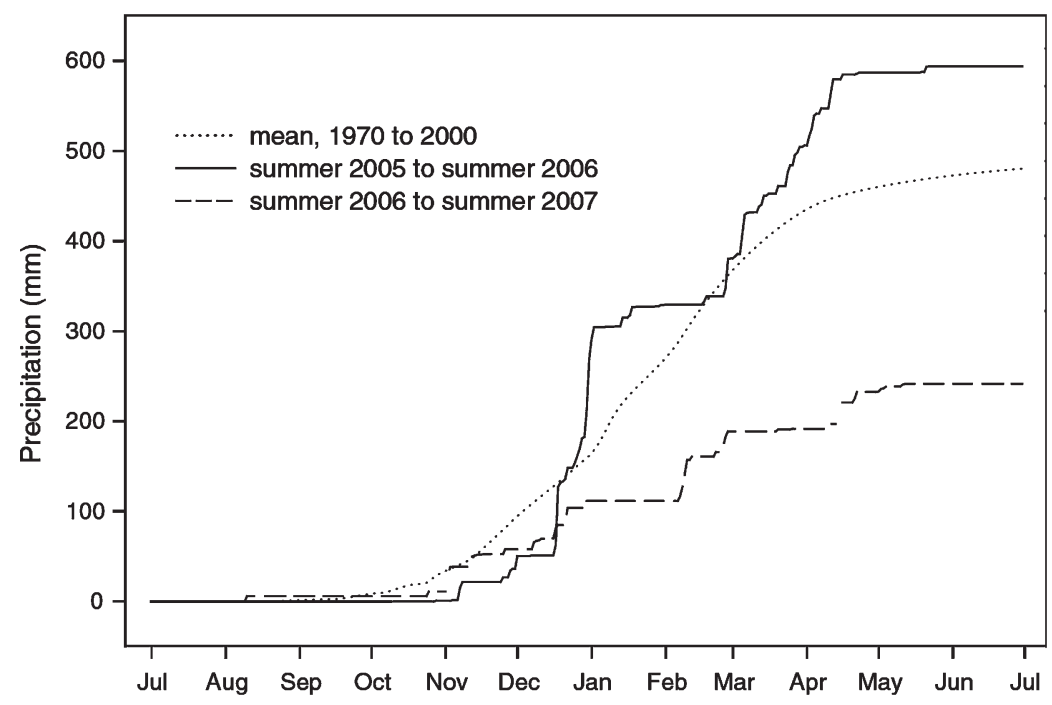

Figure 1. Cumulative precipitation at University of California, Davis in the 2005-2006 and 2006-2007 seasons.
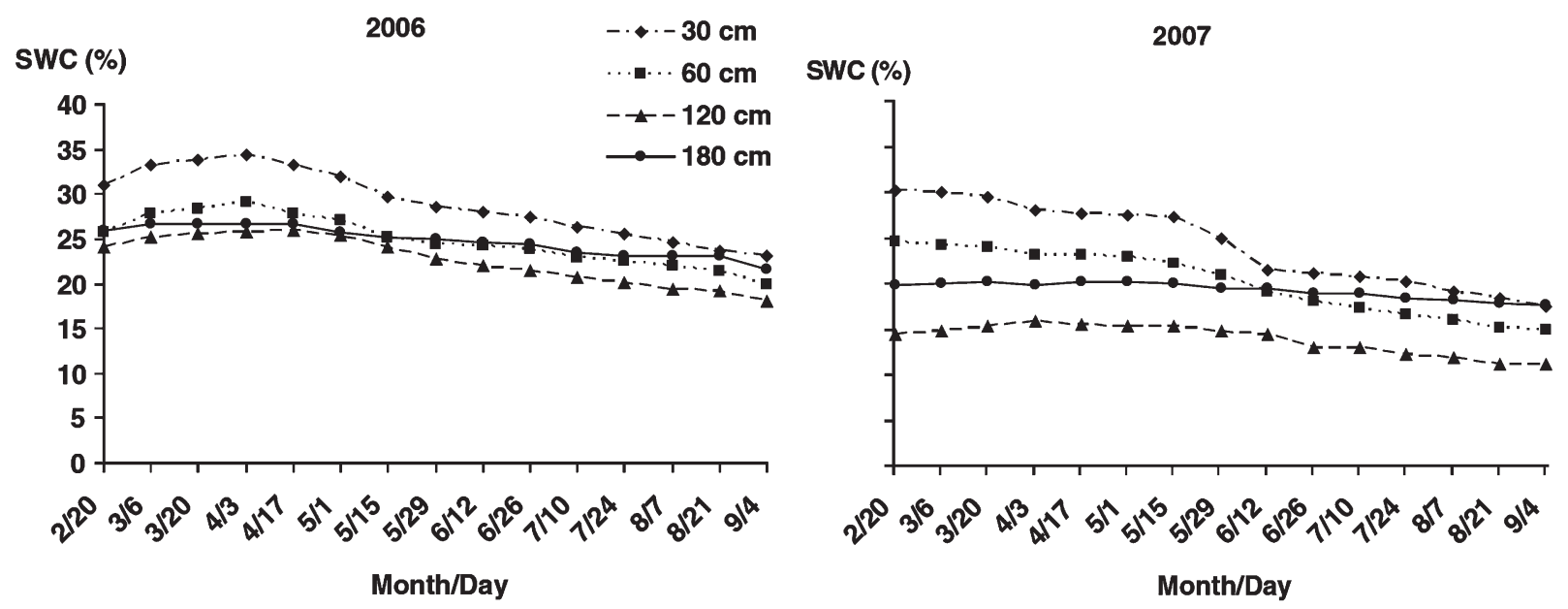

Figure 2. Seasonal pattern of soil moisture loss in bare ground for 2006 and 2007. SWC, soil water content.

2), but through evaporation dropped to approximately $18 \%$ $(-0.00 \mathrm{MPa})$ by early October of the same year. The lack of soil water recharge in 2007 resulted in only $15 \%(-0.15$ $\mathrm{MPa}$ ) soil moisture at $120 \mathrm{~cm}$ from February through May, which dropped to approximately $12 \%$ (-3.65 MPa) by October (Figure 2). Interestingly, there was little soil moisture loss from the $180 \mathrm{~cm}$ depth in both 2006 and 2007. Thus, even in the absence of vegetation, evaporation can play a significant role in water loss from the top $120 \mathrm{~cm}$ of the soil profile, reducing soil water potentials to levels considered to be below the established crop permanent wilting point (-1.5 MPa).

\section{Phenological Development}

Centaurea solstitialis rosettes established a month earlier in the wetter 2006 growing season compared with 2007 (22 February and 17 March, respectively), though bolting (15 May and 31 May), spiny (14 June and 12 June), and reproduction (12 July and 26 June) stages occurred within 2 weeks of each other between the 2 years. Growth of G. camporum at all stages was delayed by approximately 1 month due to the late winter transplanting in 2006 compared with 2007. The dates of vegetative (8 March and 6 March), inflorescence emergence (3 May and 1 May), and reproduction (14 June and 12 June) stages for Elymus glaucus were similar for both years. For E. glaucus and G. camporum, new leaf development occurred in fall, prior to the appearance of new roots.

\section{Root Growth Dynamics}

Lateral roots of C. solstitialis, which were generally 1.5$2.0 \mathrm{~mm}$ in diameter, appeared in the upper soil profile by early to mid-March in both years, and in the lower profile by late March to mid-April (Figs 3 \& 4). Root density deeper in the soil profile peaked in June 2006, when plants were in the bolting to spiny stage, and began to decline in July preceding reproduction. By early August, long before flowering was completed, there were no living roots visi- 


\section{Centaurea solstitialis}

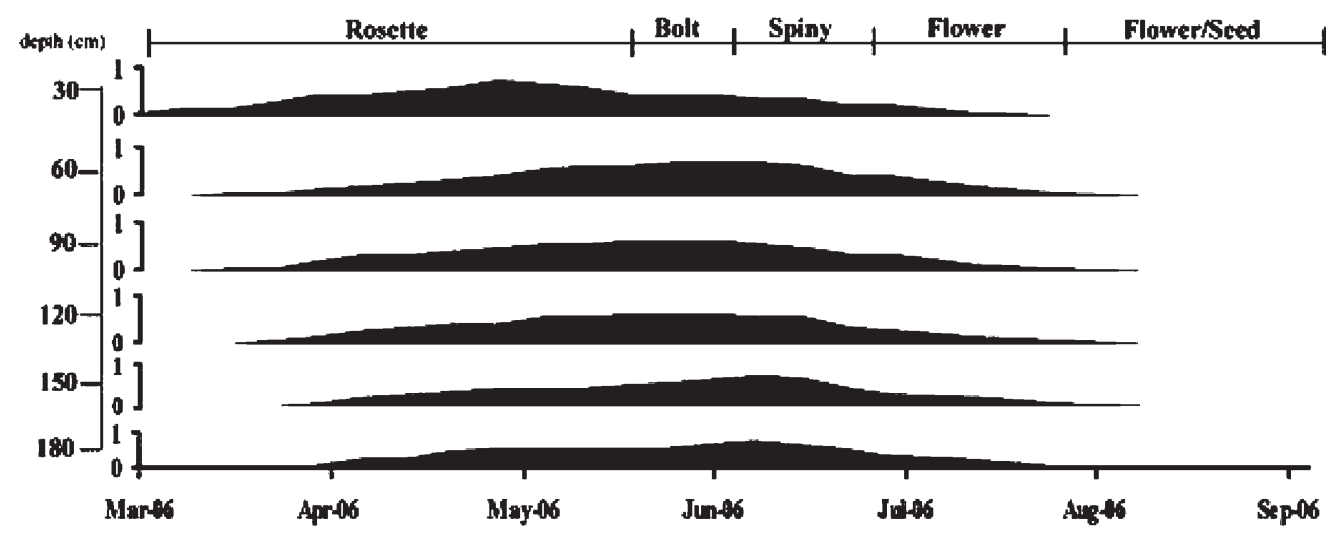

\begin{tabular}{|c|}
\hline $\begin{array}{c}\text { Percentage o } \\
\text { total } \\
17.1 \%\end{array}$ \\
\hline $16.7 \%$ \\
\hline $16.0 \%$ \\
\hline $15.8 \%$ \\
\hline $16.8 \%$ \\
\hline $17.5 \%$ \\
\hline
\end{tabular}

\section{Elymus glaucus}

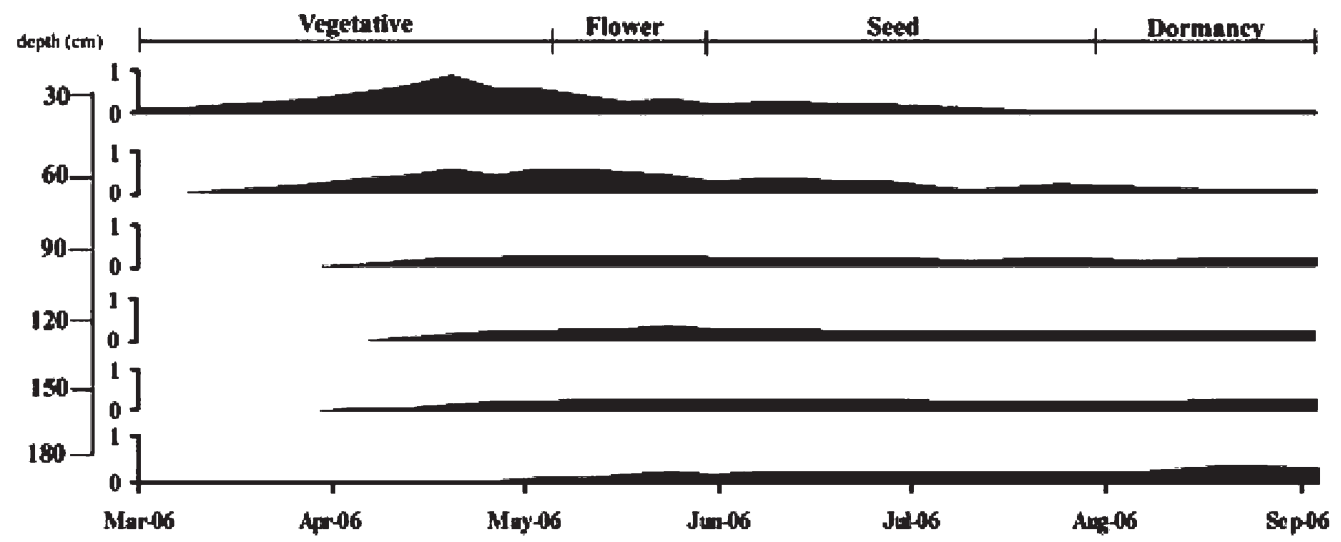

Grindelia camporum

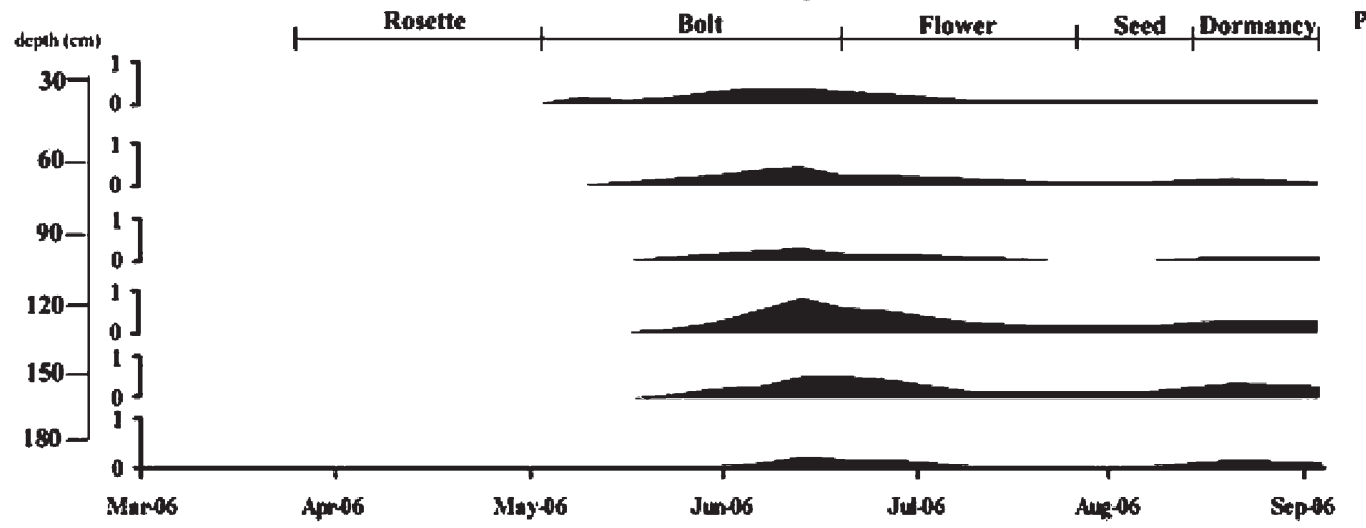

\section{Pereentage of \\ total \\ $17.0 \%$ \\ $15.6 \%$ \\ $10.8 \%$ \\ $27.2 \%$ \\ $20.9 \%$ \\ $8.5 \%$}

Figure 3. Mean live roots for Centaurea solstitialis, Elymus glaucus, and Grindelia camporum for the 2006 growing season in 30 -cm intervals in the soil. Totals are expressed in number of roots per square centimeter per week for the visible root system in underground chambers. The period of active shoot elongation, denoted as vegetative or bolt growth, and the principal periods of flowering and seed set are also indicated for each species.

ble at all depths (Figure 3). During the much drier 2007 season, peak root production occurred between late April and early May (Figure 4), but tapered off much quicker than in the wetter season in 2006. This coincided with plants in the rosette to bolting stage. The lack of deep soil moisture recharge suppressed C. solstitialis root development from 120 to $180 \mathrm{~cm}$, and completely prevented lateral root growth at $180 \mathrm{~cm}$. In 2006, the cumulative percentage of living roots was equally distributed throughout the soil profile (Figure 3 ), but in 2007, the majority of the roots (77\%) were found in the upper half of the soil profile (Figure 4). The total number of roots produced in the drought year of 2007 was 72\% less than in 2006.

Although E. glaucus was well established at the site, roots were not observed until March and May 2006 due to the time required to grow through the backfilled soil 


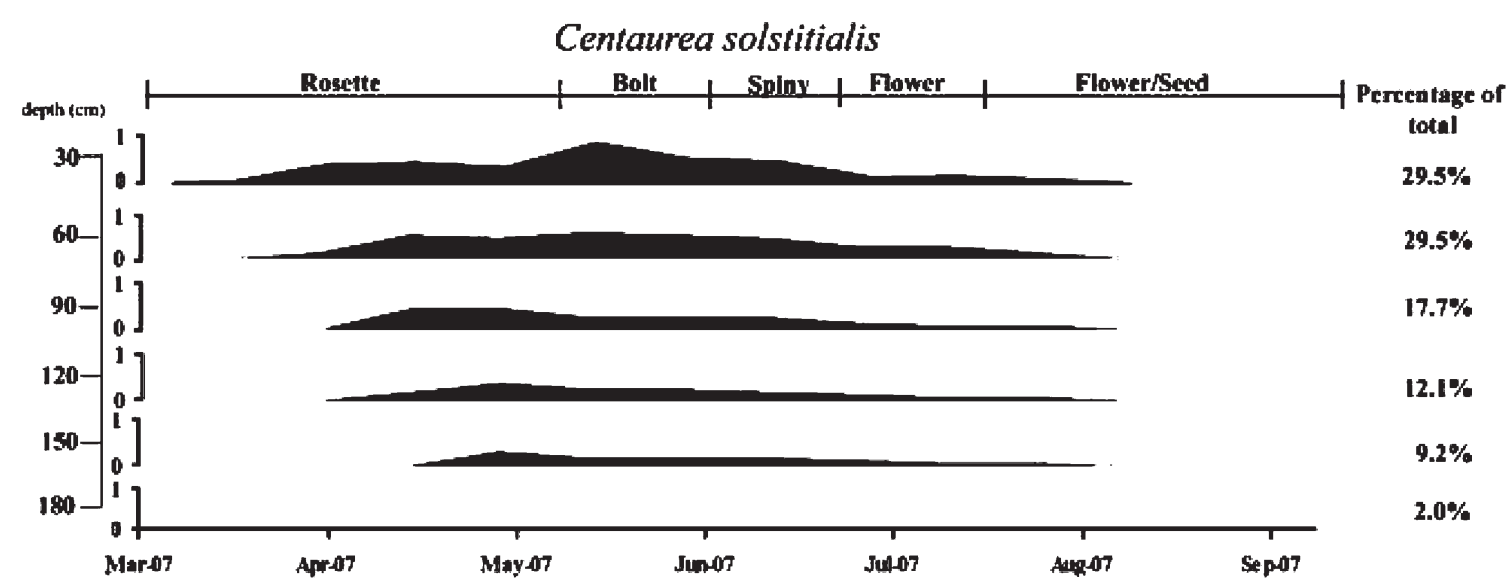

\section{Elymus glaucus}

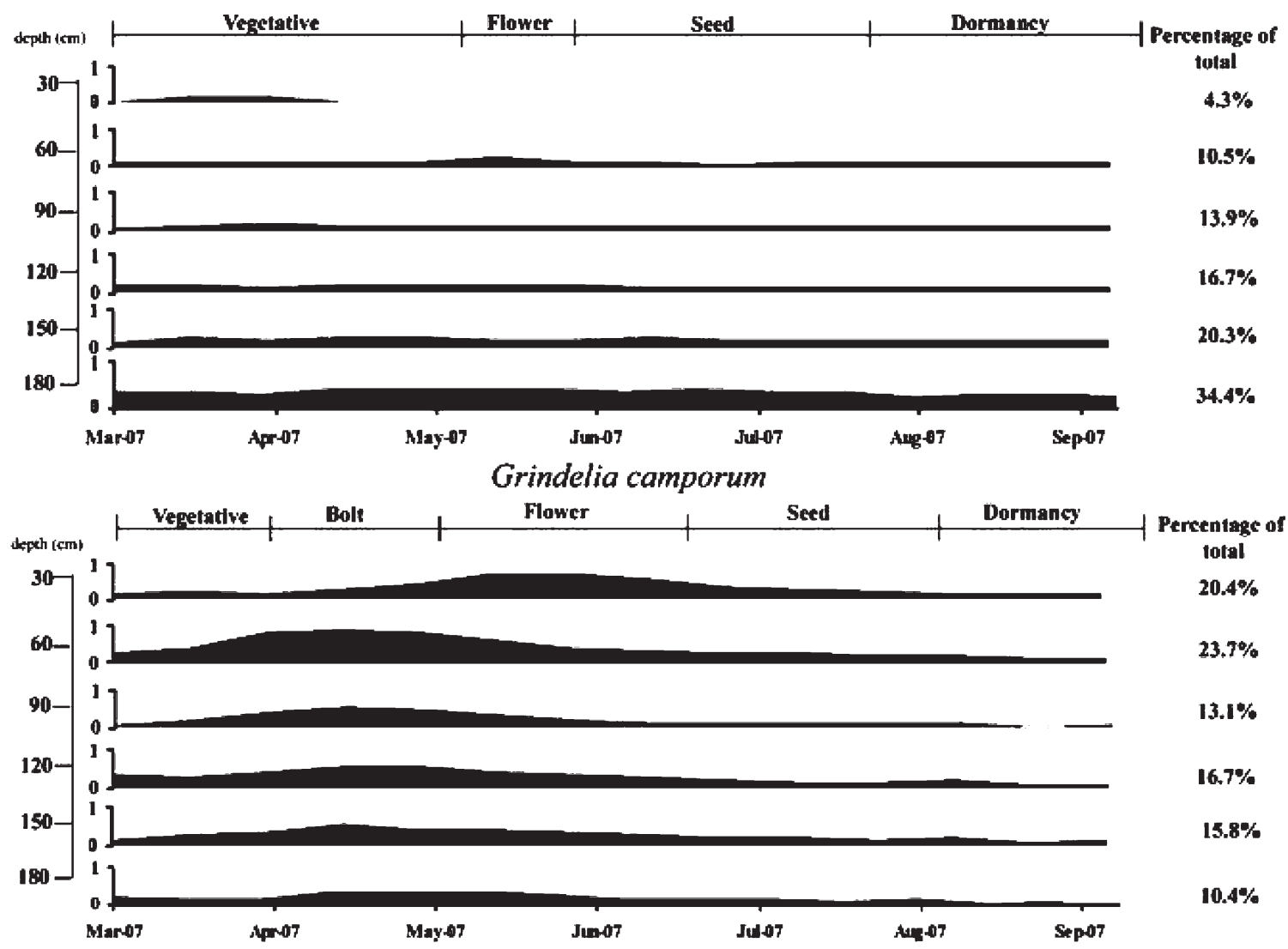

Figure 4. Mean live roots for Centaurea solstitialis, Elymus glaucus, and Grindelia camporum for the 2007 growing season in 30 -cm intervals in the soil. Totals are expressed in number of roots per square centimeter per week for the visible root system in underground chambers. The period of active shoot elongation, denoted as vegetative or bolt growth, and the principal periods of flowering and seed set are also indicated for each species.

against the observation window. Once lateral roots appeared, they persisted throughout the study except at 30 cm during the 2007 drought year (Figs. 3 \& 4). Roots of $E$. glaucus were the thinnest of the three species, with diameters of $0.3-0.6 \mathrm{~mm}$, and had fewer branching roots than the other two species. In E. glaucus, growth of shallow (30-60 $\mathrm{cm}$ ) roots peaked from mid-April to early May 2006, with some senescence occurring from June through September (Figure 3). In 2006, the cumulative percentage of living roots was $47 \%$ at 30-60 cm, and evenly distributed at lower depths (Figure 3). However, in the drier 2007 season, only $15 \%$ of the roots were found in the top $60 \mathrm{~cm}$ of the soil, and $55 \%$ were found at $150-180 \mathrm{~cm}$ (Figure 4 ). As with C. solstitialis, the total number of roots produced in 2007 was significantly lower (45\%) than in 2006.

Grindelia camporum, which was transplanted on 20 February 2006, produced roots that appeared on the glass about 3 months later, and persisted through 2007 (Figs. 3 


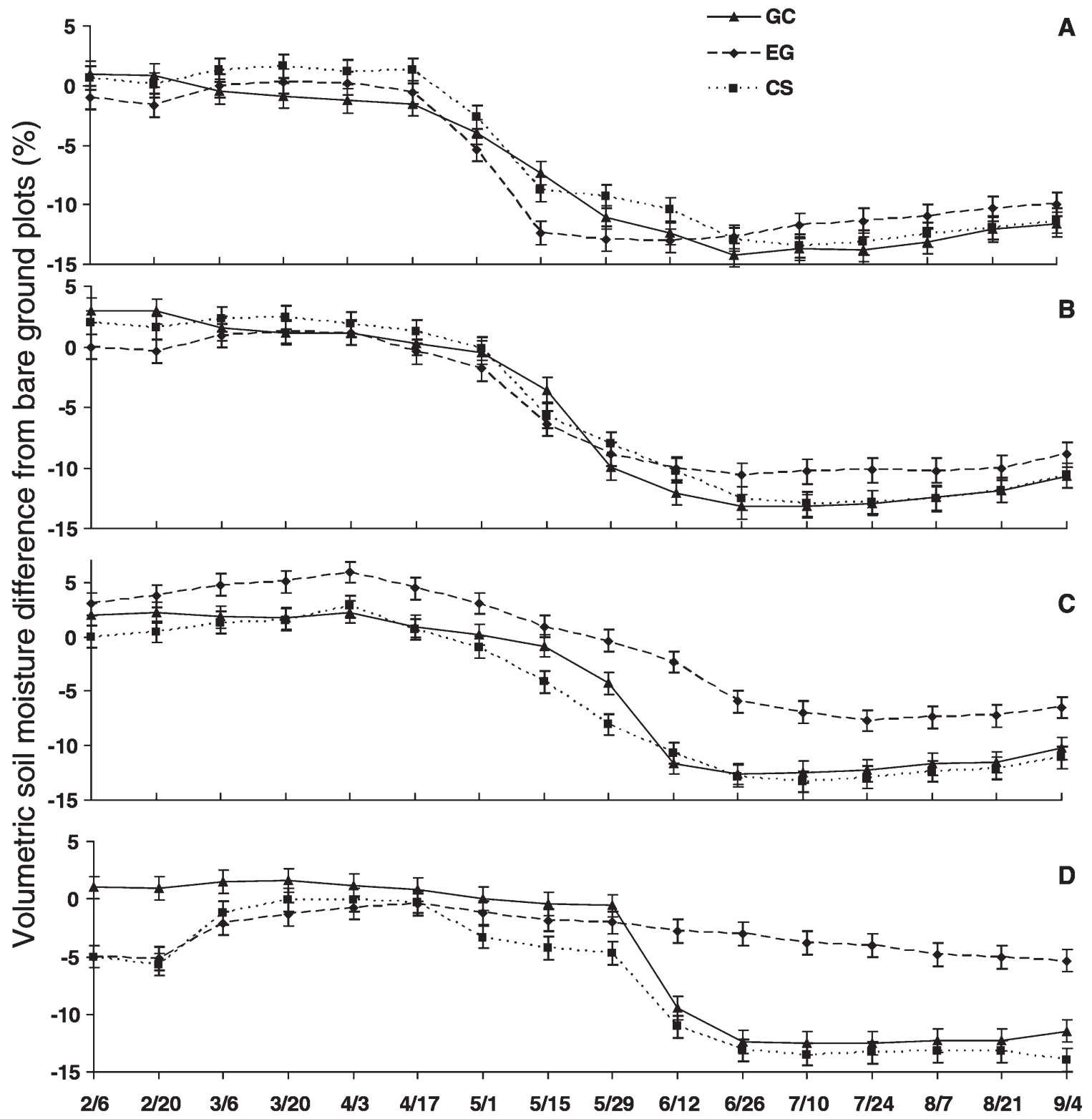

Figure 5. Soil moisture depletion for Grindelia camporum (GC), Elymus glaucus (EG), and Centaurea solstitialis (CS) in comparison to bare ground control plots (species plot-bare ground plot) at 30 (A), 60 (B), 120 (C), and 180 (D) cm for 2006. Negative values indicate greater volumetric soil moisture in the bare ground plot.

\& 4). Roots of G. camporum were of similar diameter (1.5$2 \mathrm{~mm}$ ) and morphology to those of Centaurea. Despite the delay in the appearance of roots in 2006, maximum root growth below $30 \mathrm{~cm}$ in the soil occurred during rapid stem elongation in both 2006 and 2007. Due to the delay in lateral root establishment following transplanting, it was not possible to compare cumulative root numbers between the 2 years. Unlike the other two species, the percent distribution of roots in the soil profile was not dramatically different between the 2 years.

\section{Soil Moisture Depletion Patterns}

The root distribution of these three species in the different soil layers corresponds with soil moisture deple- tion patterns during the growing season (March-September). In the wet winter and spring of 2006, soil moisture recharge was sufficient such that soil water in monoculture plots was not different from bare ground plots from 6 February through 17 April (Figure 5). All three species began to deplete soil water at $30 \mathrm{~cm}$ by 1 May 2006, and in the deeper soil by mid-May or early June (Figure 5). By mid-June, soil moisture at 30-60 cm reached a minimum for all three species. C. solstitialis and G. camporum depleted soil moisture at 120 and $180 \mathrm{~cm}$ to a minimum by 26 June, corresponding to the reproductive stage in both species, and there were no statistical differences in the total amount of water depleted by these two species in 2006 (Table 1). However, E. glaucus depleted much less deep soil moisture compared with the other two species (Fig- 
Table 1. Differences in percent soil water content (\%SWC) between Centaurea solstitialis and Grindelia camporum or Elymus glaucus at two ranges in soil depth (30 and $60 \mathrm{~cm}$ combined and 120 and $180 \mathrm{~cm}$ combined) and five Centaurea solstitialis phenological stages in 2006 and 2007.

\begin{tabular}{|c|c|c|c|c|c|c|c|c|c|c|}
\hline \multirow[b]{2}{*}{ Contrasted Plant Species (yr) } & \multicolumn{2}{|c|}{ Rosette } & \multicolumn{2}{|c|}{ Bolt } & \multicolumn{2}{|c|}{ Bud } & \multicolumn{2}{|c|}{ Early Flower } & \multicolumn{2}{|c|}{ Flower/Seed } \\
\hline & $30-60$ & 120-180 & $30-60$ & 120-180 & $30-60$ & $120-180$ & $30-60$ & 120-180 & $30-60$ & $120-180$ \\
\hline \multicolumn{11}{|l|}{ Centaurea versus Elymus } \\
\hline Centaurea \%SWC & & & & & & 13.5 & & 9.6 & & 8.4 \\
\hline Elymus \%SWC & & & & & & 22.0 & & 18.1 & & 14.9 \\
\hline 2007 ( $F$ value $)$ & NS & NS & NS & NS & 8.51 ** & NS & $7.38^{*}$ & NS & 7.28 * & NS \\
\hline \multicolumn{11}{|l|}{ Centaurea versus Grindelia } \\
\hline 2006 ( $F$ value) & NS & NS & NS & NS & NS & NS & NS & NS & NS & NS \\
\hline 2007 ( $F$ value $)$ & NS & $\underline{6.96}{ }^{*}$ & NS & NS & NS & NS & NS & NS & NS & NS \\
\hline Centaurea \%SWC & & $\overline{10.2}$ & & & & & & & & \\
\hline Grindelia \%SWC & & 9.8 & & & & & & & & \\
\hline
\end{tabular}

Numbers in bold represent $F$ values. Underlined $F$ values indicate that SWC values were greater for Centaurea solstitialis than for native species. When comparisons were significantly different at $p<0.05$, mean \%SWC values were listed for each species comparison. Significant difference occurred between plant species at levels differentiated by ${ }^{*} p<0.05,{ }^{* *} p<0.01$, or ${ }^{* * *} p<0.001$. Dash marks indicate non-significance.

ure 5). The water depletion pattern in E. glaucus was similar to C. solstitialis in the shallow soil $(30-60 \mathrm{~cm})$ throughout 2006, but E. glaucus depleted significantly less water than C. solstitialis in the deeper soils $(120-180 \mathrm{~cm})$ from the spiny to the flower/seed stage (Table 1).

A very different pattern of water depletion was measured in the drought year of 2007 (Figure 6). Although there was some soil water recharge in the shallow depths (30-60 or $90 \mathrm{~cm}$ ), little to no water penetrated deeper into the soil profile. In all species and at all soil depths, the soil moisture content as of 6 February was less than that of the bare ground plots (Figure 6). For C. solstitialis, soil water depletion occurred only at 30 and $60 \mathrm{~cm}$, reaching a minimum around 15 May, when plants were in the bolting stage. Grindelia camporum and E. glaucus also depleted only shallow soil moisture, particularly at $30 \mathrm{~cm}$, reaching a minimum by mid-May. There were few differences in SWC between $C$. solstitialis and G. camporum at each stage of $C$. solstitialis development (Table 1). In contrast, the water depletion pattern of E. glaucus compared with C. solstitialis was the opposite of that observed in 2006. Although C. solstitialis was in the spiny to flowering and seeding stages, $E$. glaucus depleted less deep soil moisture than C. solstitialis in 2006 but less shallow soil moisture during 2007. These results are consistent with root distribution data, which show that E. glaucus produced a higher percentage of deep roots in 2007 (Figure 4) compared with 2006 (Figure 3), whereas C. solstitialis had an opposite response.

\section{Discussion}

The 2 years of this study were represented by very different precipitation patterns, with the first year being a wetter than average winter and spring and the second an extremely dry winter and spring. This provided an opportunity to evaluate root growth and soil water depletion patterns in a very successful invasive species, Centaurea solsti- tialis, and two native perennial species, Elymus glaucus and Grindelia camporum, under these two conditions.

\section{Centaurea solstitialis}

In previous work using a minirhizotron camera, DiTomaso et al. (2003) showed that under full sunlight, C. solstitialis roots extended over $1 \mathrm{~m}$ into the soil profile 110 days after germination. However, this growth was primarily due to the development of a thin taproot. In this study, the first rainfall occurred in November of 2005 and 2006. Early seasonal rainfalls have been demonstrated to account for the bulk of seed germination in C. solstitialis (Benefield et al. 2001). Thus, by late February in 2006 and 2007 (approximately 120 days after the first significant rainfall), the taproots of $C$. solstitialis would be expected to have penetrated to a soil depth of at least $1 \mathrm{~m}$. At this time, however, no roots were visible on the chamber glass, even at the shallowest depth. Roots appeared on the glass wall in early March in the shallow soil depth and very soon afterwards at all other depths. This strongly suggests that the roots observed on the chamber wall were derived from lateral root development.

Root development in C. solstitialis was evenly distributed throughout the soil profile in 2006 and most prevalent in the upper $90 \mathrm{~cm}$ in the drier 2007, with production peaking in June and May, respectively. New root production ceased during the spiny stage, when seedheads were developing but had not yet reached anthesis. By mid-July, when plants were in the reproductive stage, there were few living roots remaining in the entire soil profile, which suggests that no further soil moisture depletion occurred through seed production and development. This stage is characterized by increased production of pubescence and a reflective cuticular wax to minimize water loss and heat loading (DiTomaso et al. 2006).

Seasonal rainfall and soil moisture recharge ended in early April of both 2006 and 2007. At this time, there were few lateral roots present in the soil profile. As such, it ap- 


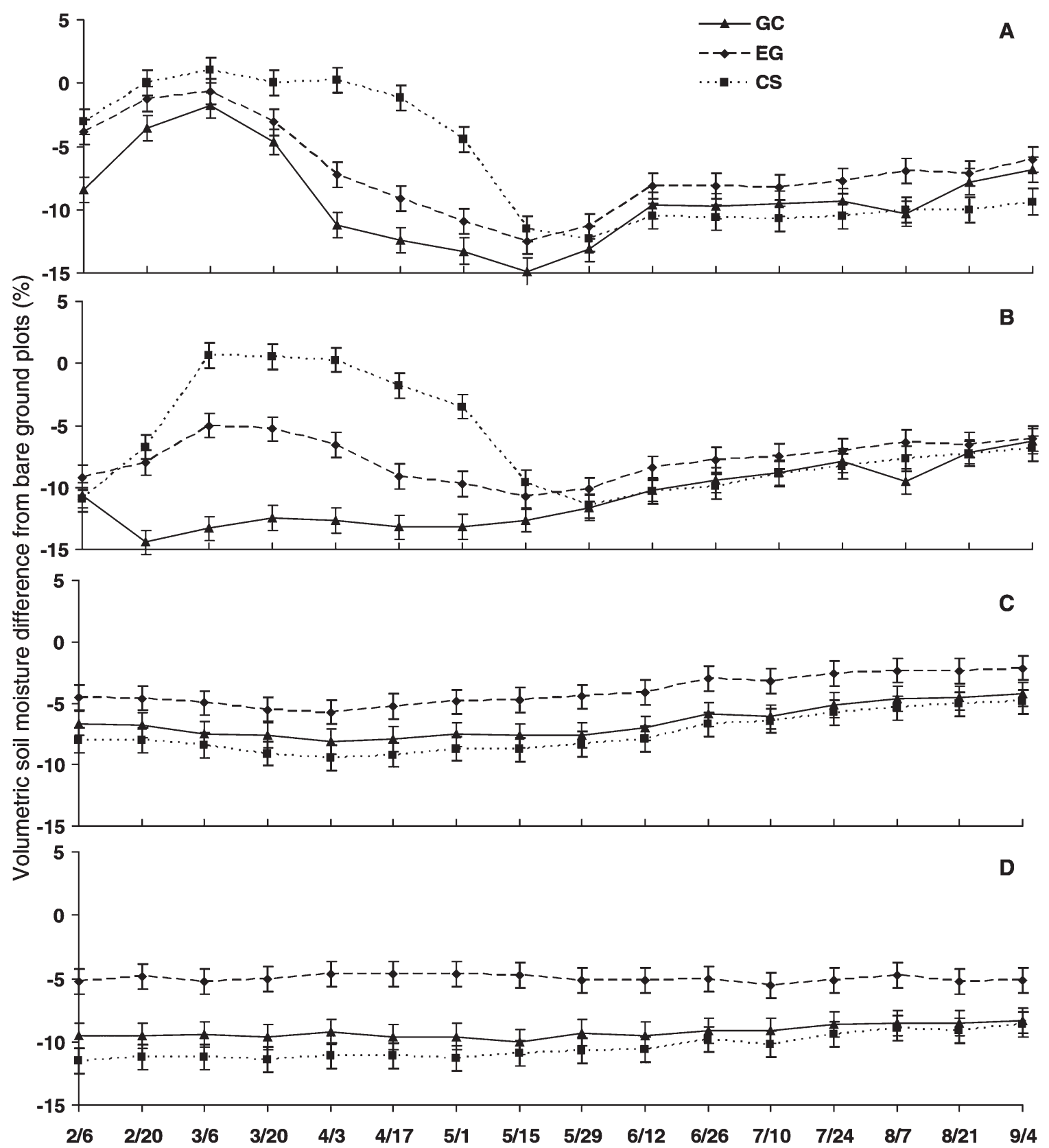

Figure 6. Soil moisture depletion for Grindelia camporum (GC), Elymus glaucus (EG), and Centaurea solstitialis (CS) by comparison to bare ground control plots (species plot-bare ground plot) at 30 (A), 60 (B), 120 (C), and 180 (D) cm for 2007. Negative values indicate greater volumetric soil moisture in the bare ground plot.

pears that the most rapid soil moisture depletion by C. solstitialis is from mid-April to no later than the end of June (end of May in 2007), and this coincides with the primary expansion of lateral roots. No further soil moisture depletion occurred by the time $C$. solstitialis had initiated flowering, even in the above average rainfall year of 2006.

When considering the timing of taproot and lateral root expansion, water acquisition, and flowering, there appear to be three distinct stages of development in the life cycle of C. solstitialis (Figure 7). The first stage (establishment) is characterized by rapid taproot growth which begins soon after germination and extends into the rosette stage (see DiTomaso et al. 2003). In the Central Val- ley of California, this occurs from around November until the beginning of March. The second stage (shoot development and expansion) begins in early March and ends in mid-June, and is characterized by the formation of lateral roots and the drawdown of soil moisture throughout the profile. At this stage, plants undergo rapid rosette expansion (DiTomaso et al. 2003), and soon thereafter bolt and reach the spiny bud stage (Benefield et al. 2001). The third stage (reproduction) begins in mid-June and extends through the remainder of the season. During this stage, lateral roots are senescing with no significant water depletion from the soil, and plants transition into flowering and seed production. 


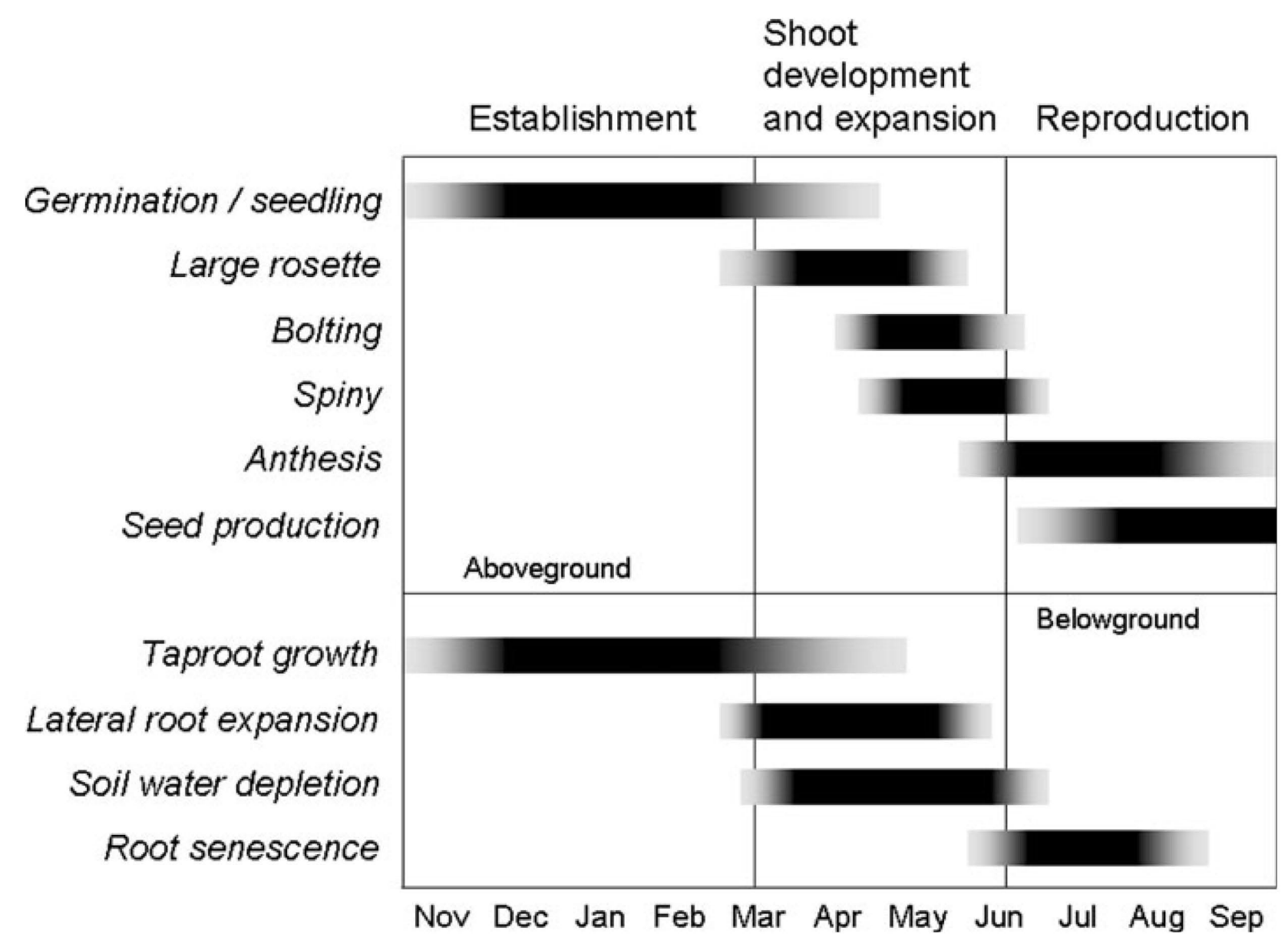

Figure 7. Time course showing the three distinct developmental stages of Centaurea solstitialis.

Although the lateral roots of $C$. solstitialis have senesced by the flowering state, we hypothesize that the taproot must continue to play a key role in the late-season survival of the plant. When the taproot is severed $30 \mathrm{~cm}$ below the soil surface, stems and foliage wilt and subsequently senesce within a couple of days (M. Pitcairn 2009, California Department of Food and Ag., Sacramento, California, U.S.A., personal communication). Thus, although it does not appear that the taproot is a major source of water uptake in the reproductive stage, it is possible that it provides critical stored water during this time period.

Under drought, C. solstitialis produced $72 \%$ fewer roots throughout the season when compared with the 2006 season. However, root distribution in the soil profile differed dramatically between the wet and dry years. In the absence of soil moisture recharge, as occurred in 2007, C. solstitialis roots either did not (1) extend their taproots into deeper soil depths, (2) produce lateral roots at these depths, or (3) survive for a long enough period to produce lateral roots in deeper soils. Even when roots were present at $120 \mathrm{~cm}$, they did not significantly deplete soil moisture. The implications of this are critical to understanding the competitive interaction between $C$. solstitialis and other grassland species. In a recent study, Young et al. (2009) showed that native annual forbs and introduced winter annual grasses were not capable of resisting C. solstitialis invasion into grassland ecosystems of California. This may occur because C. solstitialis roots are generally distributed deeper in the soil profile compared with the shallow root distribution typical of annual plants (Gerlach 2004). However, our results suggest that in years with little to no deep soil moisture recharge, C. solstitialis roots remain in the shallow regions of the soil which are typically occupied by annual grasses, thereby intensifying competitive interactions. Thus, C. solstitialis would be functionally similar to annual grasses in drought years, but in normal or wet years would be functionally similar to deep-rooted perennial species, such as E. glaucus.

\section{Elymus glaucus and Grindelia camporum}

The roots of both native perennial species survived throughout 2006 into the following year. It has been reported that late-season depletion of soil moisture induces native perennial plant dormancy in California's Mediterranean climate (Laud 1953; Holmes \& Rice 1996). Elymus glaucus and G. camporum were no longer using soil moisture at any depth by early July in 2006 or June 2007, but did not transition into dormancy until August or later in both years. This suggests that their living roots were also storing water. 
In the wet 2006 growing season, the water depletion pattern of G. camporum was very similar to C. solstitialis at all soil depths. Elymus glaucus demonstrated a similar water depletion pattern at shallower soil depths but depleted significantly less water at $120 \mathrm{~cm}$ and below. Other studies in California have similarly shown that native perennial grasses failed to deplete deep soil water during the summer season to the extent of non-native invasive species such as C. solstitialis (Holmes \& Rice 1996; Dyer \& Rice 1999; Reever Morghan \& Rice 2006). In the drought year of 2007, the two native species did not utilize soil moisture below $120 \mathrm{~cm}$ and G. camporum did not deplete water at $60 \mathrm{~cm}$. Nevertheless, roots at these depths continued to survive.

Interestingly, the root distribution pattern of E. glaucus under drought conditions was opposite to that of C. solstitialis. Although the invasive annual produced more roots at shallow soil depths $(60 \%$ of total roots at $30-60 \mathrm{~cm})$ in the drought year, E. glaucus had more roots deep in the soil ( $55 \%$ of total roots at $150-180 \mathrm{~cm}$ ), which survived despite no soil moisture recharge during the preceding rainy season. However, despite the clear difference in root distribution between C. solstitialis and E. glaucus, no water was depleted deep in the profile $(150-180 \mathrm{~cm})$ by either species. Water acquisition primarily occurred in the upper soil profile $(30-60 \mathrm{~cm})$ where E. glaucus failed to deplete soil water to the same levels as $C$. solstitialis during much of the growing season. In contrast to E. glaucus, G. camporum did not undergo a dramatic shift in root distribution within the soil profile in the very dry 2007 season, but like the other two species did not utilize deep soil moisture.

Grindelia camporum is more closely related taxonomically and morphologically to C. solstitialis and both species are characterized by late-season growth and flowering, deep roots, and similar water use timing. On the basis of these characteristics, it would appear that G. camporum would be the ideal species to compete with C. solstitialis in a restoration program. However, Young et al. (2009) found G. camporum to be a poor competitor over time, not only with C. solstitialis but also with other annual and perennial species, including E. glaucus. Although G. camporum established rapidly, it was not persistent in these systems and is not likely to provide long-term suppression of $C$. solstitialis. Thus, we concluded (Young et al. 2009) that G. camporum is an early succession species and a good colonizer in newly restored or disturbed plant communities, but is not tolerant to further disturbance or competition with other grassland species in California.

In contrast to G. camporum, E. glaucus is very competitive with C. solstitialis (Young et al. 2009). The ability of $E$. glaucus roots to persist in the soil profile throughout the year may partially explain why this species can resist invasion in ecosystems with deep, well-developed soils. This appears to support the concept of functional resistance, in which functional traits of desirable species (i.e., spatio-temporal soil water use) are matched against potential invasives in order to maximize competitiveness (Young et al. 2009). These results demonstrate that developing a restoration program for $C$. solstitialis or other invasive species requires a thorough understanding of the interactions be- tween the desirable species and potential invasives under a number of environmental and climatic conditions.

\section{Implications for Practice}

-Elymus glaucus is highly competitive with Centaurea solstitialis and can provide resistance to invasion due, in part, to similarities in soil water depletion patterns.

-In low rainfall years with subnormal deep soil moisture recharge, $C$. solstitialis roots are restricted to the upper soil profile where shallow-rooted annual species can provide competitive suppression.

-In water-limited sites infested with C. solstitialis, successful restoration will depend on management of C. solstitialis prior to initiation of stem development and expansion when most water use occurs.

\section{Literature Cited}

Benefield, C. B., J. M. DiTomaso, G. B. Kyser, A. Tschohl. 2001. Reproductive biology of yellow starthistle: maximizing late-season control. Weed Science 49:83-90.

Bugg, R. L., C. S. Brown, J. H. Anderson. 1997. Restoring native perennial grasses to rural roadsides in the Sacramento Valley of California: establishment and evaluation. Restoration Ecology 5:214-228.

Claassen, V. P., M. Marler. 2004. Annual and perennial grass growth on nitrogen-depleted decomposed granite. Restoration Ecology 6:175-180.

DiTomaso, J. M., G. B. Kyser, C. B. Pirosko. 2003. Effect of light and density on yellow starthistle (Centaurea solstitialis) root growth and soil moisture use. Weed Science 51:334-341.

DiTomaso, J. M., G. B. Kyser, M. J. Pitcairn. 2006. Yellow starthistle management guide. Cal-IPC Publication \#200603. California Invasive Plant Council, Berkeley, California, 65 pp (available from http://www.cal-ipc.org/ip/management/yst.php [accessed on 4 June 2009]).

Duncan, C. A., J. J. Jachetta, M. L. Brown, V. F. Carrithers, J. K. Clark, J. M. DiTomaso, R. G. Lym, K. C. McDaniel, M. J. Renz, P. M. Rice. 2005. Assessing economic, environmental and societal losses from invasive plants on rangeland and wildlands. Weed Technology 18:1411-1416.

Dyer, A. R., K. J. Rice. 1999. Effects of competition on resource availability and growth of a California bunchgrass. Ecology 80:2697-2710.

Enloe, S. F., J. M. DiTomaso, S. B. Orloff, D. J. Drake. 2004. Soil water dynamics differ among rangeland plant communities dominated by yellow starthistle (Centaurea solstitialis), annual grasses, or perennial grasses. Weed Science 52:929-935.

Gerlach, J. D. Jr. 2004. The impacts of serial land-use changes and biological invasions on soil water resources in California, USA. Journal of Arid Environments 57:365-379.

Gerlach, J. D. Jr, K. J. Rice. 2003. Testing life history correlates of invasiveness using congeneric plant species. Ecological Applications 13:167-179. 
Holmes, T. H., K. J. Rice. 1996. Patterns of growth and soil-water utilization in some exotic annuals and native perennial bunchgrasses of California. Annals of Botany 78:233-243.

Huntington, G. L., J. C. Wardlaw, M. Minno, W. Allardice, C. Monti, A. Shen. 1981. Soil survey of the University of California, Davis. Department of Land, Air and Water Resources, University of California, Davis, $61 \mathrm{pp}$.

Knapp, E. E., K. J. Rice. 1996. Genetic structure and gene flow in Elymus glaucus (blue wildrye): implications for native grassland restoration. Restoration Ecology 4:1-10.

Laud, H. M. 1953. The nature of summer dormancy in perennial grasses. Botanical Gazette 114:284-293.

Maddox, D. M., A. Mayfield, N. H. Poritz. 1985. Distribution of yellow starthistle (Centaurea solstitialis) and Russian knapweed (Centaurea repens). Weed Science 33:315-327.

Reever Morghan, K. J., K. J. Rice. 2006. Variation in resource availability changes the impact of invasive thistles on native bunchgrasses. Ecological Applications 16:528-539.
Roché, B. F. Jr, C. T. Roché, R. C. Chapman. 1994. Impacts of grassland habitat on yellow starthistle (Centaurea solstitialis L.) invasion. Northwest Science 68:86-96.

SAS. 2002. SAS Version 9.1.3 for Windows. SAS Institute Inc., Cary, North Carolina.

Sheley, R. L., L. L. Larson, D. E. Johnson. 1993. Germination and root dynamics of range weeds and forage species. Weed Technology 7:234-237.

Young, S. L., J. N. Barney, G. B. Kyser, T. S. Jones, J. M. DiTomaso. 2009. Functionally similar species confer greater resistance to invasion: implications for grassland restoration. Restoration Ecology 17: doi: 10.1111/j.1526100X.2008.00448.x. 